\title{
HUBUNGAN PENGETAHUAN DAN SIKAP AYAH DENGAN KELENGKAPAN IMUNISASI DASAR PADA BALITA DI PUSKESMAS SAMUDERA TAHUN 2016
}

\author{
Cut Asmaul Husna ${ }^{1}$, Yuziani ${ }^{2}$ \\ ${ }^{1}$ Bagian Mikrobiologi, Fakultas kedokteran, Universitas Malikussaleh \\ ${ }^{2}$ BagianFarmakologi, Fakultas kedokteran, Universitas Malikussaleh \\ Corresponding Author : yuziani_twins@yahoo.co.id
}

\begin{abstract}
Abstrak
Imunisasi merupakan suatu upaya untuk mencapai Millenium Development Goals (MDGs) yang bertujuan menurunkan angka kesakitan dan kematian anak akibat penyakit infeksi. Eradikasi penyakit Infeksi dengan upaya preventif imunisasi telah menunjukkan keberhasilan, meskipun cakupan imunisasi dasar lengkap belum tercapai. Cakupan imunisasi pada tahun 2014 menurun dibandingkan tahun 2013, 2014 angka cakupan imunisasi menurun dibandingkan tahun 2013, Aceh termasuk urutan ke sembilan provinsi dengan urutan cakupan imunisasi terendah tahun 2014. Banyak hal yang mempengaruhi kelengkapan imunisasi dasar pada balita salah satunya adalah dukungan keluarga. Peran ayah sebagai kepala keluarga, selain berperan sebagai pencari nafkah, pendidik, pelindung dan pemberi rasa aman, juga sebagai penentu pengambilan keputusan dalam sebuah keluarga, termasuk kaitannya dalam kesehatan anak, salah satunya dengan keikutsertaan anak dalam imunisasi. Pengetahuan dan sikap ayah perlu di teliti lebih lanjut dalam hubungannya dengan pemberian imunisasi dasar pada balita. Tujuan penelitian ini adalah untuk menilai hubungan pengetahuan dan sikap ayah terhadap pemberian imunisasi dasar pada balita di puskesmas Samudera, kabupaten Aceh Utara tahun 2016. Penelitian ini merupakan penelitian deskriptif, menggunakan metode cross sectional dengan tekhnik simple random Sampling. Hasil penelitian didapatkan responden memiliki pengetahuan baik tentang imunisasasi sebanyak $68,9 \%$ dan yang memiliki pengetahuan kurang baik sebanyak $31,1 \%$. Respoden yang memiliki sikap setuju tentang imunisasasi sebanyak $64,4 \%$ dan yang memiliki sikap tidak setuju sebanyak 35,6\% serta responde yang mengimunisasi lengkap anaknya sebanyak $22,2 \%$ dan tidak lengkap sangat banyak $77,8 \%$. Uji chi square dengan $\rho=0,019<0,05$ didapatkan sebesar 32,3\% responden berpengetahuan baik dan kelengkapan imunisasi lengkap serta nilai $\rho=0,008<0,05$ responden yaitu sebesar $34,5 \%$ bersikap setuju dan kelengkapan imunisasi lengkap dan responden sebanyak $65,5 \%$ bersikap setuju dan imunisasi tidak lengkap. Kesimpulan terdapat hubungan yang bermakna antara pengetahuan dengan kelengkapan imunisasi dan terdapat hubungan yang bermakna antara sikap dengan kelengkapan imunisasi.
\end{abstract}




\title{
ASSOCIATION BETWEEN FATHER'S KNOWLEDGE AND ATTITUDE WITH TOODLER COMPLETE BASIC IMMUNIZATION AT PUSKESMAS SAMUDERA TAHUN 2016
}

\begin{abstract}
Immunization is an attempt to achieve the Millennium Development Goals (MDGs) aimed at reducing child morbidity and mortality due to infectious diseases. Infectious disease eradication with preventive immunization efforts have shown success, although complete basic immunization coverage has not been achieved. 2014 numbers declining immunization coverage than in 2013, Aceh including the order of nine provinces with the order of the lowest immunization coverage in 2014. Many things affect the completeness of basic immunization in young children one of whom is the family support. The role of the father as the head of the family, in addition to a role as breadwinners, educator, protector and giving sense of security, as well as a determinant of decision-making in the family, including in relation to the health of children, one of them with the participation of children in immunization. Knowledge and attitudes father needs o be investigated further in connection with the provision of basic immunization in infants. The purpose of this study was to assess the association of knowledge and attitudes towards provision of basic immunization father in infants in the Puskesmas Samudera district in 2016. This study is a descriptive study, using cross sectional method with simple random sampling technique. The result showed the respondents have good knowledge about immunization as much as $68.9 \%$ and good who have less knowledge as much as $31.1 \%$. Respondents who had an attitude immunization agree on as much as $64.4 \%$ and had an attitude as much as $35.6 \%$ disagree and responde that immunizing children as much as $22.2 \%$ complete and incomplete very much $77.8 \%$. Chi square test with $\rho=0.019<0.05$ was obtained by $32.3 \%$ of respondents good knowledge and completeness of complete immunization as well as the value $\rho=0.008<0.05$ respondents ie $34.5 \%$ being agreed and complete immunization completeness and respondents as many as $65,5 \%$ to be agreed and incomplete immunization. Conclusion there is a significant relationship between knowledge and completeness of immunization and there is a significant relationship between the attitude of the completeness of immunization.
\end{abstract}

Keyword: knowledge, attitude, father, immunization 


\section{PENDAHULUAN}

Imunisasi merupakan upaya pencegahan primer yang efektif dalam mencegah terjangkitnya penyakit infeksi. ${ }^{1}$ Imunisasi merupakan suatu upaya untuk mencapai Millenium Development Goals (MDGs) yang bertujuan menurunkan angka kesakitan dan kematian anak akibat penyakit infeksi. Menurut WHO ada 1,5 juta anak mengalami kematian tiap tahunnya oleh penyakit yang sebetulnya bisa dicegah dengan imunisasi. Pada tahun 2013, lebih dari 2 juta balita melewatkan imunisasi DPT3, yang sebagian besar adalah masyarakat tidak mampu. ${ }^{2}$. Program Pengembangan Imunisasi (PPI) telah dicanangkan oleh World Health Organization (WHO) sejak tahun 1974 dengan tujuh target penyakit infeksi yaitu difteri, tetanus, pertusis, polio, campak, tuberkulosis, dan hepatitis B. Indonesia telah melaksanakan PPI sejak tahun 977. Sejak penetapan the Expanded Program on Immunisation (EPI) oleh WHO, cakupan imunisasi dasar anak meningkat dari 5\% hingga mendekati $80 \%$ di seluruh dunia. Sekurang-kurangnya ada 2,7 juta kematian akibat campak, tetanus neonatorum dan pertusis serta 200.000 kelumpuhan akibat polio yang dapat dicegah setiap tahunnya. ${ }^{3}$

Angka cakupan imunisasi masing-masing sesuai PPI pada tahun 2003 cukup tinggi yaitu BCG 97, 9\%, DTP1 96,6\%, Polio 91,8\%, Campak 89,2\%, dan Hepatitis B $79,4 \%$. Namun menurut hasil survei kesehatan nasional pada tahun 2003, cakupan imunisasi lengkap hanya mencapai $51 \%$ pada laki-laki dan $52 \%$ pada perempuan. ${ }^{4}$ Standar cakupan imunisasi untuk Indonesia yang telah ditetapkan dan wajib dipenuhi oleh instansi kesehatan termasuk Puskesmas untuk lima imunusiasi dasar yaitu 80,5\% dari jumlah bayi yang menjadi sasaran. Standar yang telah ditetapkan tersebut ditargetkan dapat dicapai pada tahun 2009. Namun kenyataannya secara umum, standar ini belum mampu dipenuhi oleh sebagian besar daerah di Indonesia. ${ }^{5}$

Salah satu upaya pemerintah adalah menyusun target imunisasi tahun 2015-2019 yaitu tercapainya cakupan imunisasi dasar lengkap kepada $93 \%$ bayi 0-11 bulan serta tercapainya $95 \%$ Kabupaten/Kota yang mencapai $80 \%$ IDL pada bayi.Cakupan imunisasi di Indonesia pada tahun 2014 mengalami penurunan menjadi 86,9\% dari 90\% capaian pada tahun 2013. Data 10 provinsi dengan capaian imunisasi terendah 
adalah Papua, Papua Barat, Kalimantan Tengah, Nusa Tenggara Timur, Maluku Utara Kalimantan Selatan, Sulawesi Tenggara, Maluku, Aceh, dan Sumatera Utara. ${ }^{6}$

Menurut hasil laporan imunisasi Provinsi Nanggroe Aceh Darussalam (NAD) sampai dengan bulan Desember tahun 2007, secara keseluruhan sebagian besar bayi yang menjadi sasaran telah mendapat imunisasi dasar meskipun masih ada bayi yang belum lengkap mendapat tindakan tersebut. Hal ini tampak dari pencapaian imunisasi campak secara kumulatif yang di bawah standar yaitu 76,43\%. ${ }^{7}$

Banyak faktor yang mempengaruhi keberhasilan pemberian imunisasi di suatu daerah. Survei drop out imunisasi di pulau Jawa pada tahun 2011-2012 yang dilakukan UNICEF Indonesia, dipantau dari sisi pengetahuan, perilaku dan praktek komunikasi mengenai Imunisasi, ditemukan beberapa tantangan dan isu utama rendahnya cakupan imunisasi, termasuk kurangnya pengetahuan orangtua tentang imunisasi, kurangnya kesadaran terhadap layanan Imunisasi di lingkungan, serta kepercayaan orangtua pada informasi yang salah tentang imunisasi karena kepercayaan tradisional. ${ }^{2}$ Menurut data Riskesdas tahun 2013, sebanyak 32,1\% anak tidak memperoleh imunisasi lengkap, dan $8,7 \%$ anak tidak mendapatkan imunisasi dengan alasan utama anak demam $(28,8 \%)$ dan alasan keluarga yang tidak mengijinkan $(26,3 \%){ }^{8}$

Alasan bayi tidak mendapatkan imunisasi lengkap adalah karena alasan informasi, motivasi dan situasi. Alasan informasi berupa kurangnya pengetahuan ibu tentang kebutuhan, kelengkapan dan jadwal imunisasi, ketakutan akan imunisasi dan adanya persepsi salah yang beredar di masyarakat tentang imunisasi. Alasan motivasi berupa penundaan imunisasi, kurangnya kepercayaan tentang manfaat imunisasi dan adanya rumor yang buruk tentang imunisasi. Alasan situasi berupa tempat pelayanan imunisasi yang terlalu jauh, jadwal pemberian imunisasi yang tidak tepat, ketidakhadiran petugas imunisasi, kurangnya vaksin, orang tua yang terlalu sibuk, adanya masalah dengan keluarga, anak yang sakit, terlalu lama menunggu dan biaya yang tidak terjangkau. Namun yang paling berpengaruh adalah karena anak sakit, ketidaktahuan orangtua akan pentingnya imunisasi, ketidaktahuan waktu yang tepat untuk mendapatkan imunisasi berikutnya dan ketakutan akan efek samping imunisasi. ${ }^{9}$

Peranan ayah sangat besar dan penting dalam suatu keluarga. Ayah memang bukan yang melahirkan buah hati tercinta, tetapi peranannya dalam tugas perkembangan 
anak sangat dibutuhkan. Tugas ayah selain untuk menafkahi keluarga, juga diharapkan menjadi teman dan guru yang baik untuk anak. ${ }^{10}$ Peranan ayah dalam keluarga yang umum adalah sebagai kepala keluarga, selain itu peran yang lainnya adalah sebagai pengambilan keputusan. ${ }^{11}$

Perilaku ayah dan kepercayaan ayah terhadap pelayanan kesehatan juga dapat mempengaruhi status imunisasi. Permasalahan yang utama dalam ketidakikutsertaan balita dalam pelaksanaan imunisasi adalah kurangnya kepercayaan oleh orangtua terhadap petugas kesehatan yaitu asumsi tentang efek samping yang diakibatkan setelah pemberian imunisasi.$^{12}$ Ayah mempunyai tanggung jawab sebagai kepala keluarga yang sangat dominan dalam pengambilan keputusan di keluarga. Peran ayah memperkuat keikutsertaan anak untuk mendapatkan imunisasi, dalam hal memberikan izin atau terkait keikutsertaan dalam imunisasi, mengingatkan jadwal imunisasi bayinya, mengingatkan bahwa keadaan panas dari bayi adalah reaksi imunisasi dan suatu keadaaan yang tidak berbahaya, bukan kontraindikasi untuk imunisasi berikutnya. Kepatuhan pemberian imunisasi dasar lebih banyak ditemukan pada dukungan dan motivasi ayah yang baik terhadap istrinya.$^{13}$

Kondisi pendidikan merupakan salah satu indikator yang kerap ditelah dalam mengukur tingkat pembangunan manusia suatu negara. Melalui pengetahuan,pendidikan berkontribusi terhadap perubahan perilaku kesehatan. Pengetahuan yang dipengaruhi tingkat pendidikan merupakan salah satu faktor pencetus yang berperan dalam mempengaruhi keputusan seseorang untuk berperilaku sehat. ${ }^{14}$

Hasil penelitian sebelumnya yang dilakukan oleh Hayati di kacamatan Baitussalam, Aceh Besar tahun 2009, menunjukkan dukungan keluarga yang rendah berpengaruh terhadap cakupan kelengkapan imunisasi dasar pada balita. ${ }^{15}$ Penelitian lain yang dilakukan oleh Setyowati tahun 2013 di Jember, menunjukkan terdapat hubungan bermakna antara peran ayah dengan keikutsertaan imunisasi DPT pada balita. ${ }^{16}$ Penelitian yang dilakukan oleh Mathilda menunjukkan tidak ada hubungan antara sikap orangtua terhadap imunisasi dengan kelengkapan imunisasi. ${ }^{17}$

Permasalahan tersebut melatarbelakangi penelitian ini untuk mengetahui sejauh mana tingkat pengetahuan dan sikap ayah dalam pemberian imunisasi pada 
balita. Peranan ayah secara optimal dalam melakukan imunisasi dapat mempengaruhi keberhasilan pemberian imunisasi.

\section{METODE}

Penelitian ini telah diadakan di puskesmas Samudera, kecamatan Samudera, kabupaten Aceh Utara, populasi pada penelitian ini adalah seluruh ayah yang memiliki balita yang tinggal di wilayah kerja puskesmas Samudera tahun 2016 berjumlah 584 orang. Sampel dalam penelitian ini adalah seluruh ayah yang memiliki balita yang tinggal di wilayah kerja puskesmas Samudera tahun 2016, yang memenuhi kriteria inklusi dan eksklusi.

Kriteria inklusi :

1. Bersedia menjadi responden penelitian

2. Ayah yang memiliki balita usia 1-2 tahun

3. Merupakan penduduk wilayah kerja puskesmas Samudera

4. Hadir pada saat pengembilan data

Kriteria eksklusi :

1. Ayah yang memiliki anak balita dengan riwayat penyakit kronis

2. Ayah yang memiliki balita dengan gizi buruk

3. Balita yang sudah tidak memiliki ayah

Sampel diambil dengan menggunakan tehnik simple random sampling. Rumus yang digunakan adalah dengan rumus Lameshow. Dengan proporsi sampel 86,9\%, didapatkan jumlah sampel sebanyak 45 orang sampel, penelitian ini merupakan penelitian deskriptif dengan rancangan cross sectional. Data yang digunakan adalah data primer dan data sekunder. Data primer dalam penelitan diperoleh melalui wawancara dan kuesioner. Data sekunder diperoleh dari data puskesmas tentang jumlah keluarga yang memiliki balita. Analisis data dilakukan dengan uji chi square untuk menilai korelasi antara kedua variabel pada tingkat kepercayaan 95\% $(\alpha=0,05)$. 


\section{HASIL PENELITIAN}

\section{Karakteristik Respoden}

Penelitian mengenai hubungan pengetahuan dan sikap ayah dengan pemberian imunisasi dasar pada balita di puskesmas samudera tahun 2016 yang telah dilakukan dan dimulai dengan pengumpulan data pada bulan November 2016 dengan jumlah sampel 45 orang.

\section{Karakteristik Responden Menurut Jenis Pekerjaan}

Karakteristik berdasarkan pekerjaan dikelompokkan menjadi 7 kategori yang diuraikan pada tabel 1 sebagai berikut:

Tabel 1 Distribusi Frekuensi Respoden Berdasarkan Perkerjaan

\begin{tabular}{lcl}
\hline Pekerjaan & n & Persentase (\%) \\
\hline Wiraswasta & 15 & 33,3 \\
PNS & 6 & 13,3 \\
Pedagang & 8 & 17,7 \\
Petani & 7 & 15,5 \\
Tukang & 3 & 6,6 \\
Kontraktor & 4 & 8,8 \\
Supir & 2 & 4,4 \\
\hline Jumlah & $\mathbf{4 5}$ & $\mathbf{1 0 0}$ \\
\hline & &
\end{tabular}

Bila dilihat dari jenis pekerjaan responden, pekerjaan responden paling banyak adalah Wiraswasta sebanyak 15 orang $(33,3 \%)$ dan paling sedikit merupakan jenis pekerjaan supir sebanyak 2 orang $(4,4 \%)$

\section{Karakteristik Responden Menurut Tingkat Pendidikan}

Distribusi frekuensi responden menurut tingkat pendidikan yang dikelompokkan menjadi 3 (tiga) kategori yang diuraikan pada tabel 2 sebagai berikut: 
Tabel 2 Distribusi Frekuensi Responden Menurut Tingkat Pendidikan

\begin{tabular}{lcc}
\hline Pekerjaan & $\mathrm{n}$ & Persentase (\%) \\
\hline Tinggi & 15 & 33,3 \\
Menengah & 21 & 46,6 \\
Rendah & 9 & 20 \\
\hline Jumlah & $\mathbf{8 7}$ & $\mathbf{1 0 0}$ \\
\hline
\end{tabular}

Berdasarkan tabel di atas didapatkan bahwa paling banyak responden berpendidikan menengah 21 orang $(46,6 \%)$ dan yang memiliki pendidikan rendah sangat sedikit sebanyak 9 orang (20\%).

\section{Karakteristik Responden Menurut Tingkat Penghasilan}

Distribusi frekuensi responden menurut tingkat penghasilan yang dikelompokkan menjadi 2 (dua) kategori yang diuraikan pada tabel 3 sebagai berikut:

Tabel 3 Distribusi Frekuensi Responden Menurut Tingkat Penghasilan

\begin{tabular}{lcc}
\hline Penghasilan & Frekuensi & Persentase (\%) \\
\hline Tinggi & 32 & 71,1 \\
Rendah & 13 & 28,8 \\
\hline Jumlah & $\mathbf{8 7}$ & $\mathbf{1 0 0}$ \\
\hline
\end{tabular}

Berdasarkan tabel di atas didapatkan bahwa paling banyak responden berpenghasilan tinggi 32 orang $(71,1 \%)$ dan yang memiliki penghasilan rendah sebanyak 13 orang $(28,8 \%)$.

Analisis Univariat

Analisis univariat dalam penelitian ini menggambarkan variabel pengetahuan dan sikap ayah terhap imunisasi yang disajikan dalam bentuk tabel distribusi frekuensi dan persentase.

Pengetahuan Responden

Hasil penelitian dari 45 responden di dapatkan data distribusi frekuensi pengetahuan seperti yang terterapada tabel 4 . 
Tabel 4 Distribusi Frekuensi Pengetahuan Responden

\begin{tabular}{lcc}
\hline Pengetahuan & Frekuensi & Persentase (\%) \\
\hline Baik & 31 & 68,9 \\
Kurang Baik & 14 & 31,1 \\
\hline Jumlah & $\mathbf{4 5}$ & $\mathbf{1 0 0}$ \\
\hline
\end{tabular}

Berdasarkan Tabel 5.4 dapat dilihat bahwa pada respoden diatas yang memiliki pengetahuan baik tentang imunisasasi sebanyak 31 Orang $(68,9 \%)$ dan yang memiliki pengetahuan kurang baik sebanyak 14 orang $(31,1 \%)$.

Sikap Responden

Hasil penelitian dari 45 responden di dapatkan data distribusi frekuensi sikap seperti yang terterapada tabel 5 .

Tabel 5 Distribusi Frekuensi Sikap Responden

\begin{tabular}{lcc}
\hline Pengetahuan & Frekuensi & Persentase (\%) \\
\hline Setuju & 29 & 64,4 \\
Tidak Setuju & 16 & 35,6 \\
\hline Jumlah & $\mathbf{4 5}$ & $\mathbf{1 0 0}$ \\
\hline
\end{tabular}

Berdasarkan Tabel 5.5 dapat dilihat bahwa pada respoden diatas yang memiliki sikap setuju tentang imunisasasi sebanyak 29 Orang $(64,4 \%)$ dan yang memiliki sikap tidak setuju sebanyak 16 orang $(35,6 \%)$.

Kelengkapan Imunisasi

Hasil penelitian dari 45 responden di dapatkan data distribusi frekuensi kelengkapan imunisasi seperti yang terterapada tabel 6 .

Tabel 6 Distribusi Frekuensi Kelengkapan Imunisasi

\begin{tabular}{lcc}
\hline Pengetahuan & Frekuensi & Persentase (\%) \\
\hline Lengkap & 10 & 22,2 \\
Tidak Lengkap & 35 & 77,8 \\
\hline Jumlah & $\mathbf{4 5}$ & $\mathbf{1 0 0}$ \\
\hline
\end{tabular}

Berdasarkan Tabel 5.6 dapat dilihat bahwa kelengkapan imunisasi diatas sangat tidak baik, dimana yang mengimunisasi lengkap hanya 10 0rang $(22,2 \%)$ dan yang tidak lengkap sangat banyak terdiri dari 35 orang $(77,8 \%)$. 
Analisis Bivariat

Analisis bivariat dalam penelitian dalam penelitian ini bertujuan untuk mengetahui hubungan pengetahuan dan sikap terhadap kelengkapan imunisasi. Uji statistik yang digunakan dalam analisis ini adalah uji Chi Square dengan nilai $\alpha \quad 0,05$ Hubungan Pengetahuan dengan Kelengkapan Imunisasi

Berdasarkan hasil pengelolaan data didapatkan hasil crosstabs antara pengetahuan dengan kelengkapan imunisasi terlihat pada tabel 7.

Tabel 7 Hubungan pengetahuan dengan kelengkapan imunisasi

\begin{tabular}{|c|c|c|c|c|}
\hline \multirow[b]{2}{*}{ Pengetahuan } & \multicolumn{2}{|c|}{$\begin{array}{l}\text { Kelengkapan } \\
\text { Imunisasi }\end{array}$} & \multirow[t]{2}{*}{ Total } & \multirow[t]{2}{*}{$p$ value } \\
\hline & Lengkap & $\begin{array}{l}\text { Tidak } \\
\text { Lengkap } \\
\end{array}$ & & \\
\hline Baik & $\begin{array}{c}10 \\
32,3 \%\end{array}$ & $\begin{array}{c}21 \\
67,7 \%\end{array}$ & $\begin{array}{c}31 \\
100,0 \%\end{array}$ & 0,019 \\
\hline \multirow[t]{2}{*}{ Kurang Baik } & 0 & 14 & 14 & \\
\hline & $0,0 \%$ & $100,0 \%$ & $100,0 \%$ & \\
\hline \multirow[t]{2}{*}{ Total } & 10 & 35 & 45 & \\
\hline & $22,2 \%$ & $\mathbf{7 7 , 8 \%}$ & $100,0 \%$ & \\
\hline
\end{tabular}

( Sumber : Data Primer, 2016)

Hasil uji chi square menunjukkan bahwa nilai $\rho=0,019<0,05$ artinya terdapat hubungan yang bermakna antara pengetahuan dengan kelengkapan imunisasi. Dari 45 responden bahwa persentase responden yaitu sebesar 32,3\% (10 orang) berpengetahuan baik dan kelengkapan imunisasi lengkap.

Hubungan Sikap dengan Kelengkapan Imunisasi

Berdasarkan hasil pengelolaan data didapatkan hasil crosstabs antara sikap dengan kelengkapan imunisasi terlihat pada tabel 8. 
Tabel 8 Hubungan Sikap dengan kelengkapan imunisasi

\begin{tabular}{|c|c|c|c|c|}
\hline \multirow[b]{2}{*}{ Sikap } & \multicolumn{2}{|c|}{$\begin{array}{l}\text { Kelengkapan } \\
\text { Imunisasi }\end{array}$} & \multirow[t]{2}{*}{ _Total } & \multirow[t]{2}{*}{$p$ value } \\
\hline & Lengkap & $\begin{array}{l}\text { Tidak } \\
\text { Lengkap }\end{array}$ & & \\
\hline Setuju & $\begin{array}{c}10 \\
34,5 \%\end{array}$ & $\begin{array}{c}19 \\
65,5 \%\end{array}$ & $\begin{array}{c}29 \\
100,0 \%\end{array}$ & 0,008 \\
\hline \multirow[t]{2}{*}{ Tidak Setuju } & 0 & 16 & 16 & \\
\hline & $0,0 \%$ & $100, \%$ & $100,0 \%$ & \\
\hline \multirow[t]{2}{*}{ Total } & 10 & 35 & 45 & \\
\hline & $22,2 \%$ & $\mathbf{7 7 , 8 \%}$ & $100,0 \%$ & \\
\hline
\end{tabular}

( Sumber : Data Primer, 2016)

Hasil uji chi square menunjukkan bahwa nilai $\rho=0,008<0,05$ artinya terdapat hubungan yang bermakna antara sikap dengan kelengkapan imunisasi. Dari 45 responden bahwa persentase responden yaitu sebesar 34,5\% (10 orang) bersikap setuju dan kelengkapan imunisasi lengkap. Pada responden sebanyak 65,5\% (19 orang) bersikap setuju dan imunisasi tidak lengkap.

\section{PEMBAHASAN}

\section{Pengetahuan Ayah tentang Pemberian Imunisasi Dasar Pada Balita}

Pengetahuan ayah tentang imunisasi dasar pada balita di Puskesmas Samudera yang didapatkan dari 45 orang responden, dengan hasil analisis data menunjukkan bahwa sebanyak 31 responden $(68,9 \%)$ memiliki pengetahuan baik dan 14 responden $(31,1 \%)$ memiliki pengetahuan kurang. Hasil penelitian ini sesuai dengan penelitian Mathilda yang menyebutkan bahwa sebagian besar responden memiliki pengetahuan yang baik terhadap imunisasi (86\%), dengan sebagian besar ayah memiliki tingkat pendidikan menengah (SMA/ SLTA sederajat). ${ }^{17}$

Pengetahuan yang baik dapat dipengaruhi dari tingkat pendidikan responden yang sebagian besar adalah SMA/SLTA (46,6\%), dan sebanyak 15 orang responden berpendidikan tinggi (D3/S1). Pendidikan responden merupakan salah satu faktor yang penting dalam meningkatkan pengetahuan karena dengan pendidikan yang baik maka responden dapat menerima segala informasi dari luar terutama tentang pemberian 
imunisasi dasar pada balita. Hal tersebut sesuai dengan pendapat Azwar makin tinggi pendidikan seseorang makin mudah juga orang itu menerima informasi, baik dari media massa maupun dari orang lain. ${ }^{18} \mathrm{Hal}$ tersebut sesuai dengan Reinberg yang menyebutkan bahwa tingkat pendidikan akan meningkatkan pengetahuan terhadap pencegahan penyakit. $^{19}$

\section{Sikap Ayah tentang Pemberian Imunisasi Dasar Pada Balita}

Sikap ayah tentang pemberian imunisasi dasar pada balita yang telah diperoleh dari 45 responden menunjukkan bahwa sebanyak 29 responden $(64,4 \%)$ menyatakan sikap setuju tentang pemberian imunisasi dasar pada balita, sedangkan 16 responden lainnya menyatakan sikap tidak setuju. Hasil penelitian menunjukkan sebanyak 50\% responden memiliki sikap yang baik terhadap imunisasi, sedangkan $50 \%$ responden lainnya memiliki sikap yang buruk terhadap imunisasi. ${ }^{20}$

Jenis pekerjaan responden yang terbanyak adalah wiraswasta yaitu sebanyak 15 orang $(33,3 \%), 8$ orang pedagang $(17,7 \%)$, petani 7 orang $(15,5 \%)$, PNS 6 orang $(13,3 \%)$ pekerjaan lainnya terdiri dari supir, kontraktor dan tukang las. Pekerjaan ayah secara tidak langsung berkaitan dengan kemampuan berinteraksi dengan orang lain dan menciptakan pengalaman baru, menurut Sukarni disebutkan bahwa pengalaman langsung yang dialami individu terhadap obyek sikap berpengaruh terhadap sikap individu terhadap obyek sikap tersebut. Selain itu informasi yang diterima individu akan dapat menyebabkan perubahan sikap pada diri individu tersebut. ${ }^{21}$ Azwar menyebutkan adanya informasi baru mengenai sesuatu hal memberikan landasan kognitif baru bagi terbentuknya sikap terhadap hal tersebut. ${ }^{18}$

\subsection{Pemberian Imunisasi Dasar Pada Balita}

Hasil penelitian ini menunjukkan dari total 45 responden yang diteliti, 35 orang diantaranya $(22,2 \%)$ yang melakukan pemberian imunisasi dasar pada balita, sedangkan sebagian besar responden $(77,8 \%)$ tidak melakukan pemberian imunisasi dasar pada balitanya. Tingginya jumlah responden yang tidak melakukan pemberian imunisasi pada balita didasarkan atas banyak alasan, terutama berkaitan dengan keraguan responden terhadap isu haram dari vaksin, alasan lainnya karena responden tersebut takut akan efek samping setelah imunisasi yang akan terjadi pada anaknya. 
Hasil penelitian ini sedikit berbeda dengan penelitian yang dilakukan oleh Mathilda yang menyebutkan bahwa jumlah responden yang telah melakukan pemberian kelengkapan imunisasi pada anak sebanyak 61\% sedangkan $39 \%$ lainnya tidak memenuhi kelengkapan imunisasi. Ada berbagai alasan yang menyebabkan responden tidak melakukan pemberian imunisasi pada anaknya, termasuk diantaranya alasan ketidaktahuan jadwal imunisasi $(34,8 \%)$ dan takut akan efek samping imunisasi $(23,5 \%){ }^{22}$

Standar cakupan imunisasi untuk Indonesia yang telah ditetapkan dan wajib dipenuhi oleh instansi kesehatan termasuk puskesmas untuk lima imunusiasi dasar yaitu $80,5 \%$ dari jumlah bayi yang menjadi sasaran. Standar yang telah ditetapkan tersebut ditargetkan dapat dicapai pada tahun 2009. Namun kenyataannya secara umum, standar ini belum mampu dipenuhi oleh sebagian besar daerah di Indonesia. ${ }^{5}$

\section{Hubungan Pengetahuan Ayah dengan Pemberian Imunisasi Dasar Pada Balita}

Berdasarkan hasil analisis data penelitian didapatkan $\mathrm{P}$ value 0,019 yang menunjukkan adanya hubungan antara pengetahuan ayah dengan pemberian imunisasi dasar pada balita. Didapatkan hasil bahwa 14 dari 45 responden memiliki pengetahuan kurang, semuanya tidak melakukan pemberian imunisasi dasar lengkap pada balitanya. Hasil penelitian ini sejalan dengan penelitian yang dilakukan oleh mathilda yang menyebutkan bahwa tingkat pengetahuan orangtua memiliki hubungan yang bermakna dengan kelengkapan imunisasi anak. ${ }^{22}$

Faktor yang mempengaruhi keikutsertaan imunisasi pada balita terdiri dari dua faktor yakni faktor internal dan faktor eksternal. Faktor internal yang mempengaruhi dukungan sosial keluarga adalah faktor emosi dan pendidikan serta tingkat pengetahuan. Faktor internal terdiri dari umur, pendidikan, pekerjaan dan informasi imunisasi. Semakin tinggi pendidikan seseorang maka semakin mudah seseorang dalam menerima informasi sehingga semakin banyak pengetahuan yang dimiliki. ${ }^{23}$ Pada penelitian ini sebagian besar responden memiliki pendidikan tinggi dan pengetahuan yang baik, tetapi hanya 10 dari 31 responden yang berpengetahuan baik tersebut yang melakukan pemberian imunisasi dasar lengkap pada balita. Hal ini sejalan dengan penelitian Hayati yang menyatakan bahwa tidak semua responden yang berpendidikan tinggi melakukan pemberian imunisasi dasar lengkap pada balitanya. ${ }^{15}$ Hal ini sesuai dengan pendapat 
Karr yang dikutip Notoatmodjo bahwa keputusan seseorang untuk bertindak tidak hanya dipengaruhi oleh pendidikan namun sebagian besar juga faktor lain terutama pada masyarakat yang masih memegang tradisi seperti Indonesia sangat dipengaruhi oleh otonomi atau kebebasan pribadi. Selain itu, tidaka adanya hubungan pendidikan dengan kelengkapan imunisasi karena informasi tentang imunisasi lebih banyak didapat melalui media masa, bukan dari sekolah atau pendidikan formal. Berdasarkan hasil jawaban responden, alasan tidak melakukan pemberian imunisasi pada balita adalah terkait isu haram vaksin dan juga takut akan efek samping imunisasi. Masyarakat Aceh yang masih kental dengan tradisi dan keislamannya lebih mudah terpengaruh dengan isu yang berhubungan dengan agama. ${ }^{24}$

Orang tua yang menolak untuk memberikan imunisasi kepada anaknya dikarenakan kurangnya pemahaman orang tua tentang pentingnya imunisasi bagi anak. Selain itu orang tua juga merasa khawatir mengenai efek samping yang ditimbulkan setelah imunisasi sebab orang tua takut anaknya sakit. Orang tua merupakan kunci dalam menjaga dan merawatanaknya. Anak dapat tumbuh dan berkembang secara sehat baik fisik maupun mental tergantung pada orang tua, terutama ayah. ${ }^{25}$ Pemahaman mengenai imunisasi sangat diperlukan orang tua sebagai dasar dalam memenuhi kebutuhan kesehatan anak. Pemberian imunisasi dasar pada anak harus dilandasi dengan adanya pemahaman yang baik dari orang tua mengenai imunisasi sebagai suatu upaya pemeliharaan kesehatan anak melalui upaya pencegahan penyakit. Sehingga orang tua diharapkan dapat menyadari dan memiliki pemahaman yang positif terhadap imunisasi. $^{26}$

\section{Hubungan Sikap Ayah dengan Pemberian Imunisasi Dasar Pada Balita}

Berdasarkan hasil penelitaian dan analisis data didapatkan adanya hubungan antara sikap ayah dengan pemberian imunisasi dasar pada balita di Puskesmas Samudera tahun 2016, dengan P value sebesar 0,08. Diketahui 16 dari 45 responden dengan sikap yang tidak setuju, tidak ada satupun yang melakukan pemberian imunisasi dasar lengkap pada balitanya. Sebaliknya hanya 10 dari 29 responden yang bersikap setuju yang melakukan pemberian imunisasi lengkap pada balitanya. Hasil penelitian ini berbeda dengan penelitian Mathilda yang menyatakan tidak ada hubungan antara sikap dengan pemberian imunisasi dasar pada balita. ${ }^{22}$ 
Kekhawatiran orangtua yang akhirnya memutuskan untuk tidak memberikan imunisasi berarti orang tua membiarkan anaknya menderita penyakit yang dapat membahayakan jiwa dimana penyakit tersebut sebenarnya dapat dicegah dengan pemberian imunisasi. Orang tua harus berperan secara aktif dalam memelihara kesehatan anak sebagai upaya untuk memaksimalkan proses pertumbuhan dan perkembangan anak terutama pada tahun pertama kehidupan anak. ${ }^{27}$

Hasil teori yang dikemukakan oleh Azwar bahwa faktor faktor yang mempengaruhi pembentukan sikap diantaranya adalah pengetahuan dan pengaruh orang lain yang dianggap penting. Kurangnya pengetahuan seseorang akan mudah terpengaruh dalam bersikap dan pada umumnya individu cenderung untuk memiliki sikap yang konformasi atau searah dengan orang yang dianggap penting seperti keluarga. ${ }^{28}$

\section{KESIMPULAN}

Berdasarkan hasil penelitian Hubungan Pengetahuan Dan Sikap Ayah Dengan Kelengkapan Imunisasi Dasar Pada Balita Di Puskesmas Samudera Tahun 2016 dapat di tarik kesimpulan:

1. Responden senyak 45 orang didapatkan memiliki pengetahuan baik tentang imunisasasi sebanyak $68,9 \%$ dan yang memiliki pengetahuan kurang baik sebanyak $31,1 \%$.

2. Respoden yang memiliki sikap setuju tentang imunisasasi sebanyak $64,4 \%$ dan yang memiliki sikap tidak setuju sebanyak $35,6 \%$

3. Responde yang mengimunisasi lengkap anaknya sebanyak 22,2\% dan tidak lengkap sangat banyak $77,8 \%$.

4. Uji chi square dengan $\rho=0,019<0,05$ didapatkan sebesar 32,3\% responden berpengetahuan baik dan kelengkapan imunisasi lengkap maka terdapat hubungan yang bermakna antara pengetahuan dengan kelengkapan imunisasi

5. Nilai $\rho=0,008<0,05$ responden yaitu sebesar $34,5 \%$ bersikap setuju dan kelengkapan imunisasi lengkap dan responden sebanyak 65,5\% bersikap setuju dan imunisasi tidak lengkap maka terdapat hubungan yang bermakna antara sikap dengan kelengkapan imunisasi. 


\section{Saran}

Berdasarkan penelitian yang telah dilakukan oleh peneliti, maka saran yang dapat diberikan adalah sebagai berikut:

1. Bagi puskesmas diharapkan dapat memberikan penyuluhan tentang pemberian imunisasi lengkap pada masyarakat

2. Bagi peneliti selanjutnya diharapkan dapat meneliti lebih bnyak variabel selain pengetahuan dan sikap.

\section{Ucapan Terima Kasih}

Terima kasih kepada Fakultas Kedokteran yang telah memdanai penelitian sehingga penulis bisa menyelesaikan penelitian ini.

\section{DAFTAR PUSTAKA}

1. Achmadi,UF.2006. Imunisasi: mengapa perlu?.Penerbit Kompas,Jakarta:pp.130

2. Kemenkes RI, 2015. Panduan Pekan Imunisasi Sedunia. Diunduh dari : http://www.promkes.depkes.go.id/ pada 7 Oktober 2016.

3. WHO,2007, Expanded program on immunization overview. Diunduh dari: http://wbln0018.worldbank.org/HDNet/HDdocs.nsf pada 1 Desember 2007.

4. DepKes RI. 2006. Badan Penelitian dan Pengembangan Kesehatan, Status kesehatan masyarakat berbasis gender: fakta dari hasil survei kesehatan nasional. Jakarta:27.

5. DepKes RI. 2007. Imunisasi: Modul Pelatihan Untuk Bidan dan Tenaga Kesehatan. Makalah yang dipresentasikan pada waktu pelatihan bidan dan tenaga kesehatan mengenai imunisasi. IDI. Aceh Timur

6. Kementerian Kesehatan RI, 2010, Keputusan Menteri Kesehatan Republik Indonesia nomor 482/MENKES/SK/IV/2010 tentang Gerakan Akselerasi Imunisasi Nasional Universal Child Immunization 2010-2014 (GAIN UCI 20102014). Jakarta

7. Dinas Kesehatan Aceh, 2008. Profil Kesehatan Provinsi Naggroe Aceh Darusalam.

8. Balitbang Kemenkes RI, 2013. Riset Kesehatan Dasar; RISKESDAS. Jakarta: Balitbang Kemenkes RI 
9. Mentri Kesehatan RI, 2010, Keputusan mentri kesehatan RI No.482. Kementrian Kesehatan RI; Jakarta.

10.Utami, 2009. Pengembangan Kreativitas Anak Berbakat; Jakart, Rineka Cipta

11. Friedman, M. M., Bowden, V. R., \& Jones, E.G., 2003. Family Nursing Research, Theory, \& Practice. Fifth Edition New Jersey : Pearson Education,Inc.

12. Suprajitno, 2004. Asuhan Keperawatan Keluarga;Aplikasi dalam Praktik. Jakarta; EGC.

13. Notoatmodjo, 2007. Kesehatan Masyarakat: Ilmu dan Seni, Rineka cipta, Jakarta.

14. Depkes RI, 2009. Sistem Kesehatan Nasional; Jakarta

15. Hayati W, Dewi Marianthi, Nurleli, 2009. Faktor-Faktor Yang Berhubungan dengan Cakupan Imunisasi Dasar pada Bayi di Desa Kajhu Kecamatan 79 Baitussalam Aceh Besar. 2009. Jurnal Keperawatan vol 1/no1.

16. Setyowati NP, Hanny Rasni, Erti Ikhtiarini Dewi. 2013. Hubungan Peran Ayah di Keluarga dengan Keikutsertaan Balita Usia 2-24 Bulan dalam Pelaksanaan Imunisasi DPT di Desa Pace Kecamatan Silo Kabupaten Jember. Program Studi Ilmu Keperawatan, Universitas Jember (UNEJ)

17. Mathilda Albertina, et al, 2008 .Kelengkapan Imunisasi Dasar Anak Balita dan Faktor-Faktor yang Berhubungan di Poliklinik Anak Beberapa Rumah Sakit di Jakarta,Sari Pediatri, Vol. 11, No. 1, Juni 2009

18. Azwar 2011, Sikap Manusia, Teori dan Pengukurannya, ed. 2, Pusaka Pelajar, Yogyakarta.

19. Reinberg, S. 2008. Life Expectancy Tied to Education. http://www.healthfinder. gov/

20. Huda, N., 2009. Gambaran Pengetahuan, Sikap dan Perilaku Ibu Tentang Imunisasi Dasar Lengkap Di Puskesmas Ciputat. Skripsi, Fakultas kedokteran \& Ilmu Kesehatan, Universitas Islam Negeri Syarif Hidayatullah; Jakarta

21. Sukarni, M., 2008. Kesehatan Keluarga dan Lingkungan; Yogyakarta, Kanisius

22. Melinda, C, 2009. Arti Seorang Ayah, http://www.melindahospital.com. Diakses tanggal 5 Oktober 2016

23. Koentjaraningrat, 2000. Kebudayaan Mentalitas dan Pembangunan (cetakan kesembilan belas). Jakarta: PT. Gramedia Pustaka Utama. 
24. Notoatmodjo,S., 2010.Ilmu Perilaku Kesehatan, PT Rineka Cipta, Jakarta

25. Friedrickson, D. D., Davis, T. C., Arnold, C. L.,Kennen. E. M., Humiston, S. G., Cross, T. J.,2004.Childhood Immunization Refusal: Provider and Parent Perceptions. Family Medicine;

26. Supartini, Y. 2004. Buku Ajar Konsep Dasar Keperawatan Anak. Jakarta: EGC.

27. Suririnah. 2010. Buku Pintar Mengasuh Batita: Panduan Bagi Orangtua untuk Merawat dan Membimbing Anak Usia 1-3 Tahun secara Sehat dan Menyenangkan. Jakarta: Gramedia Pustaka Utama.

28. Azwar, Saifuddin., 2010. Sikap Manusia Teori Dan Pengukurannya. Yogyakarta : Pustaka Pelajar Offset 